\title{
MODIFIED MERCALLI INTENSITY SCALE
}

I People do not feel any Earth movement.

II A few people may notice movement.

III Many people indoors feel movement. Hanging objects swing.

IV Most people indoors feel movement. Dishes, windows, and doors rattle. Walls and frames of structures creak. Liquids in open vessels are slightly distrubed. Parked cars rock.

V Almost everyone feels movement. Most people are awakened. Doors swing open or close. Dishes are broken. Pictures on the wall move. In some cases, windows crack. Small objects move or are turned over. Liquids may spill out of open containers.

VI Everyone feels movement. Poorly built buildings are damaged slightly. Considerable quantities of dishes and glassware, and some windows, are broken. People have trouble walking. Pictures fall off walls. Objects fall from shelves. Plaster in walls may crack. Some furniture is overturned. Small bells in churches, chapels, and schools ring.

VII People have difficulty standing. Considerable damage occurs in poorly built or badly designed buildings, old walls, spires, and other structures. Damage is slight to moderate in well-built buildings. Numerous windows are broken. Weak chimneys break at roof lines. Cornices on towers and high buildings fall. Loose bricks fall from buildings. Heavy furniture is overturned and damaged. Some sand-and-gravel stream banks cave.

VIII Drivers have trouble steering. Poorly built structures suffer severe damage. Ordinary substantial buildings partially collapse. Damage is slight in structures especially built to withstand earthquakes. Tree branches break. Houses not bolted down may shift on their foundations. Tall structures such as towers and chimneys may twist and fall. Temporary or permanent changes may occur in springs and wells; sand and mud are ejected in small amounts.

IX Most buildings suffer damage. Houses that are not bolted down move off their foundations. Some underground pipes are broken. The ground cracks conspicuously. Reserviors suffer severe damage.

X Well-built wooden structures are severely damaged and some destroyed. Most masonry and frame structures are destroyed, including their foundations. Some bridges are destroyed. Dams are seriously damaged. Large landslides occur. Water is thrown on the banks of canals, rivers, and lakes. Railroad tracks are bent slightly. Cracks are opened in cement pavements and asphalt road surfaces.

XI Few if any masonry structures remain standing. Large, well-built bridges are destroyed. Woodframe structures are severely damaged, especially near the epicenter. Buried pipelines are rendered useless. Railroad tracks are badly bent. Water, mixed with sand and mud, is ejected in large amounts.

XII Damage is total, and nearly all works of construction are damaged greatly or destroyed. Objects are thrown into the air. The ground moves in waves or ripples. Large amounts of rock may move. Lakes are dammed, waterfalls formed, and rivers are deflected. 